\title{
DAMPAK PSIKOLOGIS PELAKSANAAN SIMPAN-PINJAM TANPA BUNGA KOTA MADIUN
}

\author{
Siti Muhayati \\ Dosen Pendidikan Islam IKIP PGRI Madiun
}

\begin{abstract}
ABSTRAK
Islam sebagai agama rohmatan lil'alamiin telah memberikan peraturan dalam segala aspek kehidupan manusia, termasuk didalamnya ekonomi Islam. Inti ekonomi Islam adalah infak. Infak ialah perpindahan sesuatu baik barang maupun jasa dari seseorang kepada orang lain sesuai dengan peraturan Islam. Infak ada dua yaitu infak wajib dan sunah. Diantara infak wajib adalah aqod. Simpan-Pinjam tanpa bunga termasuk aqod. Kegiatan tersebut telah dilaksanakan oleh warga Dasa Wisma 1 Rt.37,Rw.12 Kelurahan Kejuron Kecamatan Taman Kota Madiun, dan masih jarang dilakukan oleh warga di Indonesia ini.

Dari urain diatas, maka diadakan penelitian untuk mengetahui sejauh mana dampak psikologis pelaksanaan Simpan-Pinjam tanpa Bunga Al-Barokah pada psikis anggota simpan-pinjam tanpa bunga.

Desain penelitian dengan desain faktoral 2x2, populasinya anggota Simpan-Pinjam tanpa Bunga sebesar 13 anggota. Teknik pengumpulan data dengan angket dan dukumentasi, analisa datanya dengan statistik parameter test $\mathrm{t}$.

Hasil penelitian menunjukan bahwa Pelaksaan Simpan-Pinjam tanpa Bunga berdampak posititif lebih besar dari dampak negatifnya karena harga $\mathrm{H}_{\mathrm{o}}>\mathrm{H}_{\mathrm{a}}$ baik taraf 5\% maupun $1 \%((2,06>-10,76<2,80)$. Hasil penelitian ini direkomendasikan kepada ulama, ulil amri, peneliti lain, dan LPPM
\end{abstract}

Kata kunci: Psikologis, Simpan-Pinjam, Bunga

A. Pendahuluan

Islam sebagai agama Rohmatan lil'alamin, membuat manusia dapat hidup tenang, tentram, damai, dan sejahtera. Oleh karena itu Islam memberikan peraturan yang menyangkut segala aspek kehidupan pada manusia, salah satunya peraturan tentang kegiatan manusia dalam mencapai kesejahteraan lahir dan bathin atau kegiatan manusia dalam memenuhi kebutuhannya baik lahir dan bathin yang terkenal dengan Ekonomi Islam(Arif Furqon,2002). Inti ekonomi Islam adalah Infak. Istilah Infak dalam ekonomi Islam ialah berpindah sesuatu(barang atau jasa) dari seseorang kepada orang lain didasarkan pada peraturan Islam. Infak ada dua macam yaitu infak wajib dan infak sunnah. Yang termasuk infak wajib adalah nafkah, zakat, aqod, dan waris. Yang termasuk infak sunnah ialah aqiqoh, adhiya', walimatul'ursy, hibah, wakaf dan wasiat. Diantara aqod adalah Simpan_Pinjam.

Simpan-Pinjam dalam istilah Islam adalah ariyah. Ariyah ialah memberikan manfaat sesuatu yang halal kepada yang lain untuk diambil manfaatnya dengan tidak merusak zatnya, agar dapat dikembalikan lagi zat barang tersebut(Anak ciremai,2008). Firman Allah dalam Al-Qur'an Surat Al-Maidah ayat 2 ,Artinya: Bertolong-menolonglah kamu 
atas kebajikan dan taqwa, dan janganlah kamu tolong-menolong dalam perbuatan dosa dan bermusuhan. Dan takutlah kepada Allah,sesungguhnya Allah sangat pedih siksanya. Dan Firman Allah dalam Surat Al-Ma'un ayat 7 , Artinya: Mereka enggan meminjamkan barang-barang yang berguna. Hadis Nabi Muhammad S.A.W, Artinya: Pinjaman wajib dikembalikan dan orang-orang yang meminjam sesuatu harus membayar(Riwayat Abu Daud dan Tirmizi). Meminjamkan sesuatu berarti menolong yang meminjam, tapi tolong menolong dalam dosa dan bermusuhan maka siksa Allah sangat pedih.

Istilah lain Simpan-Pinjam adalah Hutang-Piutang. Hutang-Piutang ialah memberikan sesuatu yang menjadi hak milik pemberi pinjaman kepada kepada peminjam denngan pengembalikan di kemudian hari sesuai perjanjian dengan jumlah yang sama. Menurut ahli fiqih hutang-piutang adalah transaksi antara dua pihak yang satu menyerankan uangnya kepada yang lain secara sukarela untuk dikembalikan lagi kepadanya oleh pihak kedua dengan hal serupa.

Fenomena dalam masyarakat, kegiatan Simpan-Pinjam atau Hutang-Piutang dikenakan riba atau bunga. Riba adalah menetapkan/melebihkan jumlah pinjaman saat pengembalian berdasarkan presentasi tertentu dari jumlah pinjaman pokok yang dibebankan kepada peminjam. Menurut Istilah teknis, riba berarti pengambilan tambahan dari harta pokok atau modal secara bathil. Secara umum terdapat benang merah yang menegaskan bahwa riba adalah pengambilan tambahan baik dalam transaksi jual-beli maupun pinjam-meminjam secara bathil atau bertentangan dengan prinsip muamalat dalam Islam. Hal ini sebagaimana Firman Allah dalam Surat Al-Baqoroh ayat Artinya:Orang-orang yang makan (mengambil) riba tidak dapat berdiri melainkan seperti berdirinya orang yang kemasukan syaitan lantaran (tekanan) penyakit gila. Keadaan mereka yang demikian itu, adalah disebabkan mereka berkata (berpendapat), sesungguhnya jual beli itu sama dengan riba, padahal Allah telah menghalalkan jual beli dan mengharamkan riba. Orang-orang yang telah sampai kepadanya larangan dari Tuhannya, lalu terus berhenti (dari mengambil riba), maka baginya apa yang telah diambilnya dahulu (sebelum datang larangan); dan urusannya (terserah) kepada Allah. Orang yang kembali (mengambil riba), maka orang itu adalah penghuni-penghuni neraka; mereka kekal di dalamnya. 
Penerapan riba/ bunga diduga salah satu penyebab krisis moneter yang melanda diberbagai Negara, termasuk Indonesia. Akibat krisis tersebut banyak menimbulkan kerugian, meningkatkan pengangguran, meningkatkan kejahatan dan sebagainya. Jadt Simpan-Pinjam dengan menerapkan sisitem bunga menimbulkan kegelisahan pada masyarakat (Dumairy, Ekonomi Islam, 1998)

Dari uraian diatas diketahui bahwa simpan-pinjam seharusnya tanpa bunga. Pada hakekatnya simpan-pinjam tanpa bunga salah satu bentuk tolong-menolong, gotong royong dan mempererat rasa kekeluargaan(pasal 33 ayat 1 Undang-Undang Dasar 1945). Kegiatan yang tersebut diatas telah dilaksanakan oleh sekelompok masyarakat Dasa Wisma 1, Rt 37, Rw 27 Kelurahan Kejuron Kecamatan Taman Kota Madiun. Oleh karena itu peneliti tertarik untuk menelitinya dengan judul, Dampak Psikologis Pelaksanaan Simpan-Pinjam Tanpa Bunga Al-Barokah Kota Madiun.

Dari judul penelitian yang tersebt diatas dapat dirumuskanan masalah: a. Sejauh mana dampak positif pada psikis anggota kegiatan dari pelaksanaan simpan-pinjam tanpa bunga Al- Barokah. Sejauh mana dampak negatif pada psikis anggota kegiatan dari pelaksanaan simpan-pinjam tanpa bunga Al- Barokah

Penelitian ini diadakan bertujuan untuk:a. Mengetahui dampak positif pada psikis anggota kegiatan dari pelaksanaan simpan-pinjam tanpa bunga Al- Barokah b. Mengetahui dampak negatif pada psikis anggota kegiatan dari pelaksanaan simpanpinjam tanpa bunga Al- Barokah, c. Mengetahui signifikan dampak positif dan negative pada psikis pelaksanaan simpan-pinjam tanpa bunga Al-Barokah

Manfaat Penelitian ini untuk memberi konstribusi pada:1. Ilmu Pendidikan Islam: Menambah wawasan bagi manusia pada umumnya dan bagi masyarakat Indonesia, Ekonom, Pendidik, Kampus khususnya bahwa: a. Lembaga Ekonomi Islam( keuangan Islam) tanpa bunga bisa didirikan di kelompok masyarakat kecil maupun besar. a.Transaksi keuangan Islam tanpa bunga bisa dilaksanakan dengan mudah oleh kelompok masyarakat kecil maupun besar. 3. Pendidikan Islam: a. Mengembangkan bahan ajar(Materi) Pendidikan Islam di bidang Ekonomi Islam agar mahasiswa memahami bahwa ajaran(peraturan) Ekonomi Islam tanpa ada unsure bunga bisa dilaksanakan dalam kehidupan nyata sebagai solusi masalah Ekonomi manusia atau 
masyarakat sekitarnya dimana mereka berada. 4. Psikologi Islam: a. Mengembangkan psikologi Islam agar manusia memahami bahwa untuk memenuhi kebutuhan jasmani harus diseimbangkan dengan kebutuhan rohani sehingga manusia akan mencaoai kebahagian lahir dan bathin di dunia dan di akhirat. 5. Psikologi Pendidikan Islam: Mengembangkan Psikologi Pendidikan Islam: Memeperkenalkan Islam bahwa Islam tidak hanya bermanfaat pada jasmani manusia saja tetapi juga Islam bermanfaat bagi Psikis manusia agar nantinya manusia membiasakan diri untuk memperhatikan aspek psikis selain aspek phisik. 6. Kazanah Hasil Ijtihad di Bidang Ekonomi Islam dalam hal ini tentang transaksi keuangan tanpa bunga. 7. Pilot projek bagi masyarakat yang akan melaksanakan Simpan-Pinjam tanpa bunga.

\section{B. Kajian Pustaka}

\section{Konsepsi}

a. Simpan-Pinjam.

Islam sebagai sistem hidup di dunia penuh dengan peraturan-peraturan baik peraturan manusia dengan manusia, termasuk di dalamnya Ekonomi Islam.Hakekat dari Ekonomi Islam adalah infak. Infak yaitu berpindahnya sesuatu (barang atau jasa) dari seseorang kepada orang lain sesuai peraturan Islam. Infak ada dua yakni infak wajib dan infak sunnah. Yang termasuk infak wajib ialah nafkah, zakat, waris, dan aqod, sedang yang termasuk infak sunnah adalah aqiqoh, adhiya', walimatul'ursy, hibah, wakaf, dan wasiat.

Aqod merupakan salah satu infak wajib. Yang termasuk aqod adalah jual beli, sewa-menyewa, pinjam-meminjam. Obyek pinjam-meminjam pada umumnya berupa barang, jasa atau uang. Istilah pinjam-meminjam dalam masyarakat dikenal dengan istilah Simpan-Pinjam. Simpan-Pinjam dalam bahasa Arab disebut dengan Ariyah artinya memberikan manfaat sesuatu yang halal kepada yang lain untuk diambil manfaatnya dengan tidak merusak zatnya, agar dapat dikembalikan lagi zat barang tersebut. Sebagaimana Firman Allah dalam Surat Al-Maidah ayat : 2, Artinya: Bertolong-menolonglah kamu atas kebajikan dan taqwa, dan janganlah kamu tolongmenolong dalam perbuatan dosa dan bermusuhan. Dan takutlah kepadaAllah,sesungguhnya Allah sangat pedih siksaNya.Dan Firman Allah dalam 
Surat Al-Maa'uun ayat 7, Artinya: Mereka enggan meminjamkan barang-barang yang berguna. Hadis Nabi Muhammad S.A.W: Artinya: Pinjaman wajib dikembalikan dan orang-orang yang meminjam sesuatu harus membayar (Riwayat Abu Daud dan Tirmizi)

Meminjamkan sesuatu berarti menolong yang meminjam, tapi tolong menolong dalam dosa dan bermusuhan maka siksa Allah sangat pedih.

1) Hukum Simpan-Pinjam.Asal hukum meminjamkan adalah sunat, seperti tolong menolong dengan orang lain, kadang-kadang menjadi wajib, seperti meminjamkan mukena untuk sholat, kadang-kadang menjadi haram kalau yang dipinjam itu akan berguna untuk haram. Kaidah: Jalan menuju sesuatu hukumnya sama dengan hukum yang dituju. Misalnya, seseorang yang menunjukan jalan kepada pencuri, maka keadaannya sama demgan melakukan pencurian itu.

2) Rukun Pinjaman.a) Yang meminjamkan syaratnya :*Ahli( berhak) berbuat baik sekehendaknya: anak kecil dan orang yang dipaksa, tidak meminjamkannya.*Manfaat barang yang dipinjam dimiliki oleh yang meminjamkan, walau dengan jalan wakaf atau menyewa, karena meminjam hanya bersangkutan dengan manfaat, bukan bersangkutan dengan zat. Oleh karena yang meminjamkan tidak boleh meminjamkan barang yang dipinjamnya karena manfaat barang yang dipinjam boleh diambilnyam bukan mikiknya. Hanya dia dizinkan mengambilnya, dan diizinkan untuk membagikan manfaat yang boleh diambilnya kepada yang lain, misalnya: dia meminjam rumah satu bulan, ditinggalinya hanya lima belas hari, sisanya ( lima belas hari) boleh diberikan kepada orang lain.b) Yang meminjam syaratnya:*Dia orang yang ahli(berhak) mendapatkan kebaikan dan mampu bertanggung jawab. Anak kecil dan orang gila tidak sah meminjagm karena tidak mampu bertanggung jawab.c). Barang yang dipinjam: syaratnya:*Barangnya ada manfaat dan halal *Sewaktu barang diambil manfaatnya, zatnya tetap (tidak rusak), oleh karenanya makanan dengan sifat untuk dimakan. Tidak dipinjamkan. d) Shighot Pinjaman syaratnya:*Ada ijab dari yang meminjam *Ada qobul dari yang meminjamkan atau yang diberi kuasa e) Mengambil manfaat barang yang dipinjam. Orang yang meminjam boleh mengambil manfaat dari barang yang dipinjam sesuai dengan perjanjian atau kurang dari perjanjian dan tidak boleh lebih dari perjanjian. Misalnya: petani meminjam tanah untuk ditanami padi, maka tanah 
tersebutboleh ditanami padi atau tanaman lain seusia padi atau tanamn yang kurang dari usia padi, kacang.f) Hilangnya Barang Yang D[pinjam:*Wajib mengembalikan Pinjaman.*Barang yang dipinjam wajib dikembalikan sebagaimana barang tersebut dipinjam

Istilah lain dari Simpan-Pinjam adalah Hutang-Piutang. Hutang-Piutang ialah memberikan sesuatu hak milik pemberi pinjaman dengan mengembalikan di kemudian hari sesuai perjanjian dengan jumlah yang sama. Jika yang dipinjamkan berupa uang maka Hutang-Piutang adalah transaksi antara dua pihak yang satu menyerahkan uangnya kepada yang lain secara sukarela untuk dikembalikan lagi kepadanya oleh pihak kedua dengan hal serupa.

Hukum Hutang Piutang

Hukum Hutang-Piutang sama dengan Simpan-Pinjam sama juga hukumnya dengan Pinjam-Meminjam yaitu sunnah, hukumnya menjadi haram apabila uang yang diutang untuk berbuat ma'siat. Misalnya untuk beli narkoba, beli minuman keras atau untuk berjudi dan lain sebagainya.

Rukun Hutang-Piutang:*Ada yang berhutang/peminjam/piutang/debitur.*Ada yang memberi hutang/kreditur.*Ada ijab-Qobul.*Ada barang atau uang yang dipinjamkan

Dari uraian diatas bisa difahami bahwa Simpan-Pinjam sama dengan PinjamMeminjam sama dengan Hutang-Piutang, namun dalam Simpan-Meminjam mengandung kegiatan menyimpan(uang) dimana uang tersebut berasal dari simpanan uang anggota kegiatan yang selanjutnya diutangkan kepada anggota lain yang meminjam.

b. Bunga

Istilah Bunga dalam Islam adalah Riba. Riba ialah menetapkan bunga melebihkan jumlah pinjaman saat pengembalian berdasarkan persentasi tertentu dari jumlah pinjaman pokok, yang dibebankan kepada peminjam. Riba secara bahasa bermakna ziyadah(tambahan). Dalam pengertian lain, secara linguistic riba juga berarti tumbuh dan membesar. Sedangkan menurut istilah teknis, riba berarti pengambilan tambahan dari harta pokok atau modalmenetapkan bunga melebihkan jumlah pinjaman 
saat pengembalian berdasarkan persentasi tertentu dari jumlah pinjaman pokok, yang dibebankan kepada peminjam. Riba secara bahasa bermakna ziyadah (tambahan). Dalam pengertian lain, secara linguistic riba juga berarti tumbuh dan membesar. Sedangkan menurut istilah teknis, riba berarti pengambilan tambahan dari harta pokok atau modal secara bathil. Ada beberapa pendapat dalam menjelaskan riba, namun secara umum ierdapat benang merah yang menegaskan bahwa riba adalah pengambilan tambahan, baik dalam transaksi jual beli maupun pinjam meminjam secara bathil atau bertentangan dengan prinsip muamalat dalam Islam.

Dalam Islam, memungut riba atau mendapatkan keuntungan berupa riba pinjaman adalah haram. Sebagaiman Allah berfirman dalam Al-Qur'an Surat Asyuaro ayat 177-183: Artinya:(Ingatlah) ketika Syu'aib berkata kepada mereka(penduduk Aikah):"Mengapa kamu tidak bertaqwa?". Sesungguhnya aku adalah seorang rasul yang telah mendapatkan kepercayaan untukmu. Karena itu bertaqwqlah kepada Allah dan ta'atilah aku. Aku sama sekali tidak menuntut upah darimu untuk ajakan ini, upahku tidak lain dari hanyalah dari Tuhan penguasa seluruh alam. Tepatilah ketika kaтu menakar dan jangan sampai kamu menjadi orang-orang merugi. Timbanglah dengan timbangan yang tepat. Jangan kamu rugikan hak-hak orang (lain) dan janganlah berbuat jahat dan menimbulkan kerusakan di muka bumi.

Dalam ayat tersebut diatas manusia tidak boleh mengambil hak orang lain, berbuat jahat(uang dijadikan komoditas) dan berbuat rusak di muka bumi(krisis moneter). Firman Allah juga dalam Surat Al-Baqoroh ayat 275 Allah berfirman:

Artinya:Orang-orang yang memakan riba tidak akan berdiri melainkan seperti pendirian orang yang diharu setan dengan tanparannya. Yang demikian, lantaran mereka berkata:"Perdagangan itu tidak lain melainkan seperti riba".Dan Allah halalkan perdagangan dan haramkan riba. Lantaran itu barang siapa kedatangan nasehat dari Tuhannya, lalu dia berhenti maka baginyalah apa yang telah lalu, dan urusannya kepada Allah. Tetapi barang siapa kembali lagi, maka mereka ahli neraka yang mereka kekal didalamnya.

Atas dasar ayat tersebut diatas maka semarak tumbuh Bank Syari’ah, dimana konsep keuntungan bagi penabung didapat dari system bagi hasil bukan dengan bunga 
seprti pada bank konvensional, karena menurut sebagaian pendapat ulama termasuk Majlis Ulama Indonesia, bunga bank termasuk kedalam riba.

Akad atau transaksi dikatakan riba apabila bunga bank ditetapkan diawal akad. Misalnya seseorang menabung atau meminjam uang dengan tingkat suku bunga tertentu sudah ditetapkan awal akad/transaksi. Hal ini berdampak sangat panjang pada transaksi berikutnya. Jika suku bunga telah ditetapkan bagi penabung maka untuk menutupinya bunga tersebut dibebankan pada pengusaha yang meminjam modal pada bank tersebut dan apapun yang terjadi, kerugian pasti akan ditanggung oleh peminjam. Berbeda dengan system bagi hasil yang hanya memberikan bagian(nisbah) tertentu pada deposannya dari keuntungan secara riil yang didapat sesuai dengan nisbah yang disepakati. Misalnya nisbahnya 60\% 40\%, maka bagian deposannya $60 \%$ dari total keuntungan yang didapat dari pihak lain.

\section{1) Jenis Riba}

Secara garis besar riba dikelompokan menjadi dua, yaitu:

a) Riba hutang -piutang. Riba hutang-piutang terbagi lagi menjadi:*Riba qardh adalah suatu manfaat atau tingkat kelebihan tertentu yang disyaratkan terhadap yang berhutang. Riba Jahiliyyah adalah hutang dibayar lebih dari pokoknya, karena peminjam tidak mampu membayar pada waktu yang ditetapkan b) Riba jual-beli. Riba jual beli dibagi: *Riba Fadhl adalah pertukaran antar barang sejenis dengan kadar atau takaran yang berbeda, sedang barang yang dipertukarkan itu termasuk dalam jenis barang jenis ribawi *Riba Nasi'ah adalah penangguhan penyerahan atau penerimaan jenis barang ribawi yang dipertukarkan dengan jenis barang ribawi lainnya. Riba dalam nasi'ah muncul karena adanya perbedaan, perubahan, atau tambahan antara yang diserahkan sa'at ini dengan yang diserahkan kemudian.

Dari uraian diatas bahwa riba dalam segala jenis diharamkan, baik dalam akad/transaksi simpan-pinjam uang maupun barang. Menurut Al-Qur'an baik orang yang memungut bunga maupun yang ditarik bunga tidak dapat duduk karena kemasukan syetan, mereka merasa tidak aman(tenang), yang meminjamkan menghitung-hitung kekayaannya sedang yang pinjam dengan bunga mencari uang kesana kemari untuk membayar bunga. 
c. Psikis

Manusia adalah makhluk eksis dan berusaha eksis, berbeda dengan makhluk nyata lain yang ada di bumi ini dan tidak berusaha ada. Manusia berusaha eksis dan mempunyai phisik dan psikis maka mereka memenuhi kebutuhannya, baik kebutuhan phisiknya maupun psikisnya.

Menurut A. Maslow, kebutuhan manusia dapat digradasikan sebagai berikut:

1) Kebutuhan Fisiologi, 2) Kebutuhan Rasa aman, 3). Kebutuhan dimiliki dan dicinta,

4) Kebutuhan harga diri, 5). Kebutuhan Aktualisasi diri

Al-Waisol dalam buku Psikologi Kepribadian (2007), menambahkan adanya kebutuhan meta, misalnya kebutuhan keadilan, kebutuhan akan peraturan dan lain-lain.

Menurut Al-Waisol juga bahwa kebutuhan rasa aman menjadi dalam berbagai bentuk antara lain adalah praktek beragama dan keyakinan filsafat agar nantinya selamat didunia sampai akhirat (2007:244).

Zakiah Daradjat dalam bukunya Peranan Agama dalam kesehatan Mental membagi kebutuhan manusia atas dua kebutuhan pokok: Kebutuhan Primer, yaitu kebutuhan jasmani: makan, minum, seks dan lain sebagainya. Kebutuhan Sekuender, Yaitu : kebutuhan Rohani: jiwa dan sosial. Selanjutnya kebutuhan sekuender dibagi enam yaitu: 1) Kebutuhan akan rasa kasih saying, 2) Kebutuhan akan rasa aman, 3) Kebutuhan akan rasa harga diri, 4) Kebutuhan akan rasa bebas, 5) Kebutuhan akan rasa sukses 6) Kebutuhan akan rasa ingin tahu

Jallaluddin dalam bukunya Psikologi Agama(1997) menjelaskan bahwa kebutuhan manusia dikelompokan menjadi tiga yaitu: 1). Kebutuhan Individu, misalnya homeostatis, regulasi temperature, tidur, lapar dan seks, 2) Kebutuhan social, misalnya: pujian dan hinaan, kekuasaan dan mengalah, pergaulan, imitasi dan simpati, perhatian, 3) Kebutuhan akan Agama, misalnya: pengakuan Adanya Allah, pengakuan adanya peraturan Allah yang mengatur segala aspek kehidupan manusia, pelaksanaan peraturan Allah baik yang terkait dengan individu manusia itu maupun yang terkait dengan hubungan dengan manusia lain. 
Dari uraian diatas dapat difahami bahwa rohani manusia membutuhkan akan pelaksanaan peraturan agama(Islam), tidak saja terkait dengan hablum minallah nya saja tetapi juga terkait dengan social termasuk didalamnya kegiatan ekonomi(simpan-pinjam tanpa bunga) agar selamat di dunia dan akhirat.

\section{Hipotesa Penelitian}

Berdasarkan tinjauan pustaka maka dapat diambil hipotesa sebagai berikut: a. Pelaksanaan Simpan-Pinjam tanpa Bunga berdampak positif lebih besar dari berdampak negatif, b. Pelaksanaan Simpan-Pinjam tanpa Bunga berdampak negatif lebih kecil dari berdampak positif.

\section{Metode Penelitian}

\section{Desain Penelitian}

Sesuai dengan tujuan penelitian sebagaimana telah dikemukakan di depan, maka penelitian ini memggunakan pendekatan ex-post-facto. Ex-post-facto artinya sesudah fakta. Ex-post-facto sebagai pendekatan penelitian menunjuk pada perlakuan atau manipulasi variabel bebas $\mathrm{x}$ telah terjadi sebelumnya, sehingga peneliti tidak perlu memberikan perlakuan lagi, tinggal melihat efeknya pada variable terikat. Metode ini digunakan dengan pertimbangan ada data yang diungkap berada pada diri responden. Dengan metode ini, peneliti tidak perlu mengungkap data penelitian dengan eksperimen khusus. Penggunaan metode expost-fakto ini dipandang cukup representatif untuk mengetahui dampak psikologis pelaksanaan simpan-pinjam tanpa bunga . Penelitian ini disajikan dengan desain faktoral 2x2, jika digambarkan sebagai berikut:

\section{Tabel 3.1 Tentang Desain Faktoral 2x2}

\begin{tabular}{|l|c|c|}
\hline \multirow{2}{*}{ Variabel Bebas } & \multicolumn{2}{|l|}{ Psikis Anggota Simpan Pinjam Tanpa Bunga } \\
\cline { 2 - 3 } & Pre Kegiatan & Pasca Kegiatan \\
\hline
\end{tabular}




\begin{tabular}{|l|c|c|}
\hline (Kegiatan Simpan- & A & A \\
Pinjam Tanpa Bunga) & & B \\
\cline { 2 - 3 } & B & \\
\hline
\end{tabular}

\section{Variabel-Variabel Penelitian Dan Definisi Operasional}

Variabel-Variabel Penelitian adalah a.Simpan-Pinjam Tanpa BungaSimpanPinjam Tanpa Bunga adalah suatu kegiatan dimana semua/sebagian anngota kegiatan menyimpan uangnya pada ketua pelaksana yang selanjutnya uang yang terkumpul dipijamkan kepada anggota yang membutuhkan tanpa diberi/ditarik bunga baik yang menyimpan maupun yang meminjam. Kegiatan Simpan-Pinjam Tanpa Bunga ini sebagai variable bebas.b.Psikis Anggota Simpan Pinjam Tanpa Bunga. Psikis manusia adalah salah satu unsure yang ada pada manusia yang harus dipenuhi kebutuhannya antara lain aman menyimpan uang dan atau meminjam uang tanpa bunga, bukan karena tempat uangnya dan atau yang meminjam seorang kaya tetapi karena melaksanakan peraturan Agama (Islam).

\section{Populasi Dan Sampel Penelitian}

a. Populasi.Populasi dalam penelitian ini adalah semua anggota kegiatan simpan-pinjam tanpa bunga Al-Barokah di Dasa Wisma Rt.37 Rw.12 Kelurahan Kejuron Kecamatan Taman Kota Madiun. Mereka berjumlah dua belas Kepala Keluarga.

b. Sampel. Populasi Penelitian ini berjumlah dua belas KK(dua belas orang karena yang menjadi anggota hanya para ibu). Mengingat populasinya kecil maka semua anggota Simpan-Pinjam Tanpa Bunga dijadikan sampel(Isaac dan Michail dalam Metodologi Penelitian Pendidikan Kopetensi dan Prakteknya,Sukardi:2003). Isaa' telah membuat table mengenai jumlah populasi sampelnya,maka menurut Isaa' jika populasinya 10 maka sampelnya10. Populasi penelitian ini ada 12 responden maka mereka semua dijadikan sampel.

\section{Lokasi Penelitian}

Penelitian ini lokasinya di lapangan yaitu mengambil tempat di Dasa Wisma I Rw.37 Rw.12 Kelurahan Kejuron Kecamatan Taman Kota Madiun, karena di Dasa 
Wisma tersebut masyarakatnya telah melaksanakan kegiatan Simpan-Pinjam Tanpa Bunga, minimal selama lima tahun.

5. Teknik Pengumpulan Data dan Instrumen Penelitian

a. Dokumentasi. Dokumntasi ini digunakan untuk mengumpulkan data tentang nama para anggota dan kegiatan Simpan- Pinjam tanpa bunga

b. Angket. Angket ini digunakan untuk mengumpulkan data tentang kegiatan SimpanPinjam Tanpa Bunga dan dampak psikologis pelaksanaan kegiatan tersebut. Angket tentang kegiatan Simpan-Pinjam Tanpa Bunga sejumlah 10 butir soal, untuk pre tes dan paska tes sedang angket untuk dampak psikologis juga 10 butir soal baik pre tes maupun paska tes.Untuk kepentingan analisis data penelitian maka hasil angket tentang dampak psikologis pelaksanaan simpan-pinjam tanpa bunga dirubah dari data kualitatif menjada data kuantitatif, Teknik perubahan ini mengacu pendapat Saifuddin Anfal seperti dapat dilihat pada table tersebut

Perubahan data dari data kualitatif menjadi data kuantitatif

Tabel 3.2 Tentang Perubanan Data Kualitatif Menjadi Data Kuantitatif

\begin{tabular}{|l|c|c|}
\hline \multicolumn{1}{|c|}{ Jawaban } & Ya & Tidak \\
\hline Skor untuk pre tes & 0 & 1 \\
\hline Skor untuk paska tes & 1 & 0 \\
\hline
\end{tabular}

\section{Teknik Analisa Data}

Data yang terkumpul akan dianalisa dengan teknik korelasi, karena tujuan penelitian ini untuk mengetahui perbedaan dampak psikologis pelaksanaan simpanpinjam tanpa bunga dengan mengkorelasikan data simpan-pinjam dengan bunga dengan simpan pinjam tanpa bunga.

Langkah analisa data:a. Mendeskripkan data, b. Mentabulasi data, c.Mengkorelasikan variable penelitian 


\section{HASIL PENELITIAN DAN PEMBAHASAN}

\section{Deskripsi Data}

a. Profil Kegiatan Simpan-Pinjam Tanpa Bunga, 1) Letak Geografis. Kegiatan SimpanPinjam Tanpa Bunga terletak di Dasa Wisma 1, Rt. 37. Rw 12 Kelurahan Kejuron Kecamatan Taman Kota Madiun, atau di jalan Panglima Sudirman gang Jambe. Dari alun alun ke Timur berjarak 1km., 2) Keberadaan Kegiatan Simpan-Pinjam Tanpa Bunga. Kegiatan Simpan- Pinjam Tanpa Bunga didirikan para ibu Dasa Wisma 1 Rt 37, Rw 12 Kelurahan Kejuron kecamatan Taman pada tanggal 22 Desember 2005. Kegiatan ini integrasi dengan kegiatan Dasa Wisma yang diadakan tiap tanggal 22. Selain Kegiatan Simpan-Pinjam tanpa Bunga di Dasa Wisma tersebut ada juga kegiatan arisan, pengumpulan dana sosial, GNOT, dan sampah. Pengelola Kegiatan Simpan-Pinjam tanpa Bunga d[pegang oleh salah satu anggota Dasa Wisma bernama Titin Sumarni. Dia bertugas untuk mengumpulkan uang saham, simpanan, wakaf tunai, angsuran tanpa bunga dan membagikan uang yang telah terkumpul kepada anggota yang meminjam uang.

b. Regulasi Kegiatan Simpan-Pinjam Tanpa Bunga yaitu: 1) Tiap anggota Dasa Wisma bisa menjadi anggota Kegiatan Simpa-Pinjam Tanpa Bunga yang bersifat sukarela.2). Uang yang dipinjam wajib dikembalikan dengan angsuran maksimal enam kali tanpa bunga, 3) Jika ada anggota yang tidak disiplin maka diberi sangsi untuk tidak pinjam lagi dengan jeda satu bulan, 4) Pinjaman wajib lunas pada 20 hari menjelang Hari Raya, guna dibagikan uang simpanan bagi anggota yang menyimpan uangnya di kegiatan Simpan-Pinjam tanpa Bunga, 5) Jika ada sisa uang setelah diambil uang simpanan anggota maka sisa uang tersebut dipinjamkan lagi pada anggota yang meminjam

Regulasi keanggotaan Kegiatan Simpan-Pinjam Tanpa Bunga adalah:1) Anggota Kegiatan Simpan-Pinjam Tanpa Bunga yaitu anggota dan domisili di dasa Wisma 1 Rt. 37, Rw.12, Kejuron, Taman, Kota Madiun.2) Membayar Saham 3) Disunahkan menyimpan uang pada Kegiatan Simpan-Pinjam Tanpa Bunga 4) Disunahkan membayar wakaf tunai( uang) sesuai kemampuan psikisnya 5) Ta'at pada peraturan yang telah disepakati pada awal berdirinya Kegiatan Simpan-Pinjam Tanpa Bunga 6) Bersedia menerima sanksi apabila melanggar peraturan.। 
Nama para anggota Kegiatan Simpan-Pinjam Tanpa Bunga adalah: 1) Ibu Endro 2) Ibu Marsudi, 3) Ibu Supardi A, 4) Ibu Windarto, 5) Ibu Supardi B, 6). Ibu Sayuni 7) Ibu Rifa'i 8) Ibu Nasri 9) Ibu Marjoko 10) Ibu Bandrio 11) Ibu Anggoro 12) Ibu Bejan 13) Ibu Supardan

2. Tabulasi

Data yang dikumpulkan ditabulasikan sebagai berikut

Tabel 4.1 Tentang Skor Responden Pra Kegiatan

\begin{tabular}{|l|l|c|}
\hline No & Responden Pra Kegiatan & Skor \\
\hline 1 & Ibu Endro & 4 \\
\hline 2 & Ibu Marsudi & 5 \\
\hline 3 & Ibu Supardi A & 4 \\
\hline 4 & Ibu Windarto & 4 \\
\hline 5 & Ibu Supardi B & 3 \\
\hline 6 & Ibu Sayuni & 5 \\
\hline 7 & Ibu Rifa'i & 3 \\
\hline 8 & Ibu Nasri & 4 \\
\hline 9 & Ibu Marjoko & 5 \\
\hline 10 & Ibu Bandrio & 5 \\
\hline 11 & Ibu Anggoro & 5 \\
\hline 12 & Ibu Bejan & 3 \\
\hline 13 & Ibu Supardan & 10 \\
\hline & Jumlah & 60 \\
\hline
\end{tabular}

Dari tabel diatas dapat diketahui bahwa bahwa jumlah skor responden pra kegiatan 60 dengan rerata 4,62

Tabel 4.2 Tentang Skor Paska Kegiatan

\begin{tabular}{|r|l|r|}
\hline No & Responden Paska Kegiatan & \multicolumn{1}{|c|}{ Skor } \\
\hline 1 & Ibu Endro & 10 \\
\hline 2 & Ibu Marsudi & 10 \\
\hline 3 & Ibu Supardi A & 10 \\
\hline 4 & Ibu Windarto & 10 \\
\hline 5 & Ibu Supardi B & 10 \\
\hline 6 & Ibu Sayuni & 10 \\
\hline 7 & Ibu Rifa'i & 10 \\
\hline 8 & Ibu Nasri & 10 \\
\hline 9 & Ibu Marjoko & 10 \\
\hline
\end{tabular}




\begin{tabular}{|r|l|r|}
10 & Ibu Bandrio & 10 \\
\hline 11 & Ibu Anggoro & 10 \\
\hline 12 & Ibu Bejan & 10 \\
\hline 13 & Ibu Supardan & 10 \\
\hline \multicolumn{2}{|r|}{ Jumlah } & 130 \\
\hline
\end{tabular}

Dari tabel diatas dapat diketahui bahwa skor responden paska kegiatan 130 dengan rerata 10

Tabel 4.3 Tentang Skor Responden Pra dan Paska Kegiatan

\begin{tabular}{|c|c|c|c|}
\hline No & $\begin{array}{c}\text { Skor Pra } \\
\text { Kegiatan }\end{array}$ & $\begin{array}{c}\text { Skor Paska } \\
\text { Kegiatan }\end{array}$ & Jumlah \\
\hline 1 & 4 & 10 & 14 \\
\hline 2 & 5 & 10 & 15 \\
\hline 3 & 4 & 10 & 14 \\
\hline 4 & 4 & 10 & 14 \\
\hline 5 & 3 & 10 & 13 \\
\hline 6 & 5 & 10 & 15 \\
\hline 7 & 3 & 10 & 13 \\
\hline 8 & 4 & 10 & 14 \\
\hline 9 & 5 & 10 & 15 \\
\hline 10 & 5 & 10 & 15 \\
\hline 11 & 5 & 10 & 15 \\
\hline 12 & 3 & 10 & 13 \\
\hline 13 & 10 & 10 & 20 \\
\hline Jumlah & 60 & 130 & 190 \\
\hline
\end{tabular}

Dari tabel diatas dapat diketahui bahwa jumlah skor respoden pra kegiatan dan paska kegiatan 190 dengan rerata 9.5

3. Pengujian Persyaratan Analisis

Analisa penelitian ini menggunakan Statistik Parametris dengan t test karena $N_{1}=N_{2}$ dan varians homogens, untuk mengetahui t tabel digunakan $\mathrm{df}=\mathrm{n}_{1}+\mathrm{n}_{2}-2$

\section{Pengujian Hipotetis}

Hipotesa penelitian ini dengan uji fihak kiri sehingga rumusan hipotesis nol dan alternatifnya sebagai berikut: $\mathrm{H}_{\mathrm{o}}$ : Pelaksanaan Simpan-Pinjam tanpa Bunga berdampak positif sama atau lebih besar dari dampak negatif, $\mathrm{H}_{\mathrm{a}}$ : Pelaksaan Simpan-Pinjam tanpa Bunga Berdampak negatif lebih kecil dari berdampak positif ,Atau dapat ditulis dalam bentuk: $\mathrm{H}_{\mathrm{o}}: \mu_{1} \geq \mu_{2}, \mathrm{H}_{\mathrm{a}}: \mu_{1} \leq \mu_{2}$ 
5. Pembahasan Hasil Penelitian

a. Analisa Data. Data yang telah ditabulasikan dianalisa sebagai berikut

Tabel 4.4 Tentang Perhitungan Mean Dan Standar Deviasi

\begin{tabular}{|c|c|c|c|c|c|c|}
\hline & \multicolumn{2}{|c|}{ Nilai } & \multirow{2}{*}{$x$} & \multirow{2}{*}{ Y } & \multirow{2}{*}{$x^{2}$} & \multirow{2}{*}{$Y^{2}$} \\
\hline & $x$ & $\mathrm{Y}$ & & & & \\
\hline & 4 & 10 & $-0,61538$ & 0 & 0,378698 & 0 \\
\hline & 5 & 10 & 0,384615 & 0 & 0,147929 & 0 \\
\hline & 4 & 10 & $-0,61538$ & 0 & 0,378698 & 0 \\
\hline & 4 & 10 & $-0,61538$ & 0 & 0,378698 & 0 \\
\hline & 3 & 10 & $-1,61538$ & 0 & 2,609467 & 0 \\
\hline & 5 & 10 & 0,384615 & 0 & 0,147929 & 0 \\
\hline & 3 & 10 & $-1,61538$ & 0 & 2,609467 & 0 \\
\hline & 4 & 10 & $-0,61538$ & 0 & 0,378698 & 0 \\
\hline & 5 & 10 & 0,384615 & 0 & 0,147929 & 0 \\
\hline & 5 & 10 & 0,384615 & 0 & 0,147929 & 0 \\
\hline & 5 & 10 & 0,384615 & 0 & 0,147929 & 0 \\
\hline & 3 & 10 & $-1,61538$ & 0 & 2,609467 & 0 \\
\hline & 10 & 10 & 5,384615 & 0 & 28,99408 & 0 \\
\hline Jumlah & 60 & 130 & 0 & 0 & 39,07692 & 0 \\
\hline Rerata & 4,615385 & 10 & & & & \\
\hline $\begin{array}{l}\text { Standar } \\
\text { Deviasi }\end{array}$ & 1,733758 & 0 & & & & \\
\hline
\end{tabular}

Dari tabel dapat diketahui bahwa jumlah skor responden pra kegiatan $\left(\sum X\right)=60$, rerata $=4.615385, \sum X^{2}=39,07692, \sum Y^{2}=0$, Standar Deviasi $=1,733758$. Sedangkan jumlah skor responden $=130$, rerata $=10$, Standar Deviasi $=1,733758$

b. Harga t.Dari hasil perhitungan ( perhitungannya bisa dilihat dalam lampiran) maka didapat harga $t_{0}=-10,76$ berarti berarti hasil perhitungan $t_{0}$ lebih kecil dari $t_{\text {tabel }}$ baik dalam taraf signifikan $5 \%$ maupun pada taraf $1 \%(2,06>-10,76<2,80)$. Dengan demikian $\mathrm{H}_{\mathrm{a}}$ ditolak dan $\mathrm{H}_{\mathrm{o}}$ diterima, yang berarti Pelaksanaan Simpan-Pinjam tanpa Bunga berdampak positif lebih besar dari dampak negatifnya.

c. Pembahasan.Dari hasil penelitian dapat diketahui bahwa Pelaksanaan Simpan-Pinjam tanpa Bunga berdampak positif pada psikis manusia.Hal ini sesuai dengan pendapat Al Waishol bahwa manusia merasa aman apabila melaksanakan ajaran Islam kususnya pelaksanaan ajaran Allah tentang haram memakan riba atau bunga dari peminjaman uang. Juga sesuai dengan firman Allah dalam surat Al-Baqoroh 275. Artinya: Orang orang yang memakan riba tidak akan berdiri melainkan seperti pendirian orang yang 
diharu setan dengan tanparannya. Yang demikian, lantaran mereka berkata:"Perdagangan itu tidak lain melainkan seperti riba".Dan Allah halalkan perdagangan dan haramkan riba. Lantaran itu barang siapa kedatangan nasehat dari Tuhannya, lalu dia berhenti maka baginyalah apa yang telah lalu, dan urusannya kepada Allah. Tetapi barang siapa kembali lagi, maka mereka ahli neraka yang mereka kekal didalamnya.

Ayat tersebut diatas menjelaskan bahwa orang yang mengambil riba atau bunga dari uang yang dipinjamkan seperti orang yang tidak dapat duduk bagaikan orang yang kemasukan syetan,artinya orang yang hatinya tidak tenang, tidak aman karena ada kekwatiran uangnya tidak kembali beserta bunganya. Sedang yang meminjam juga merasa tidak aman karena harus memikirkan mengembalikan uang yang dipinjam dan harus membayar bunganya. Sehingga baik yang meminjam dan yang meminjamkan, mereka tidak merasa aman

\section{E. PENUTUP}

1. Simpulan

Perumusan masalah dari penelitian ini adalah: a. Sejauh mana dampak positif pada psikis anggota kegiatan dari pelaksanaan simpan-pinjam tanpa bunga Al- Barokah b. Sejauh mana dampak negatif pada psikis anggota kegiatan dari pelaksanaan simpanpinjam tanpa bunga Al- Barokah

Berdasarkan kajian pustaka, masalah masalah tersebut dapat dirumuskan hipotesa sebagai berikut: a. Pelaksanaan Simpan-Pinjam Tanpa Bunga memiliki dampak positif lebih besar daripada dampak negatifnya. b. Pelaksanaan Simpan-Pinjam Tanpa Bunga berdampak negatif lebih kecil dari berdampak positif. c. Pelaksanaan Simpan-Pinjam Tanpa Bunga berdampak positif lebih besar dari berdampak negatif, karena hasil penelitian menunjukan bahwa $\mathrm{H}_{\mathrm{o}}$ lebih kecil dari $\mathrm{H}_{\mathrm{a}}$ baik dalam taraf $5 \%$ atau $1 \%(2,06-10,76<2.80)$ jadi ada pembeda antara pra dan paska Pelaksanaan Simpan-Pinjam Tanpa Bunga.

2. Saran

Dengan memperhatikan hasil penelitian diatas maka perlu penulis sampaikan beberapa saran sebagai berikut: Pertama, kepada Ulama untuk membimbing, memberi contoh dan bersedia diajak berdialog dengan siapa saja yang mempunyai niat untuk 
mendirikan Simpan-Pinjam Tanpa Bunga. Kedua, kepada ulil amri atau pengelola Negara ini untuk memayungi kegiatan Simpan-Pinjam tanpa Bunga demi kemanusiaan yang adil dan beradab dan keadilan sosial bagi seluruh rakyat Indonesia dalam rangka mengisi dan memperkuat sila pertama yaitu ketuhanan yang Maha Esa Ketiga, kepada peneliti lain yang berkenan mengadakan penelitian sejenis guna memnyebar luaskan hasil penelitian sehingga masyarakat terinspirasi melaksanakan Simpan-Pinjam Tanpa Bunga. Keempat, kepada LPPM IKIP PGRI Madiun hendaklah memfasilitasi semua penelitian yang terkait ilmu tanjiliah karena manusia perlu memahami ilmu tanjiliah guna bekal sebagai kholifah fil ard.

3. Implikasi Penelitian

Implikasi Penelitian ini adalah: 1. Menambah wawasan manusia tentang bukti bahwa Islam adalah agama Rohmatan lil 'alamiin. 2. Memberi contoh pada manusia untuk saling membantu secara jama'ah tanpa memeras orang lain

\section{DAFTAR PUSTAKA}

Ahmed, Habib, and Muhammad Umer Chapra.2002.Corporate Governance In

Islamic Financial Institutions.Islamic Development Bank

Ahmad, Mushtaq.1995.Business Ethics in Islam.Pakistan: International Institute of Islamic Thought Islamabad

Al-Miqdas-Edisi 71 Lembar Jum'at.1996.Suku Bunga Tinggi Rendah Sama

Saja. Yogyakarta: Forum Al-Ummah

Ali, Sakti.2007. Analisis Teoritis Ekonomi Islam; sebagai jawaban atas kekacauan ekonomi modern,Aqsa Publishing

Al-Waisol.2007.Psikologi Kepribadian.2007.Malang:UMM pres

At Tabari Ali Said.Firdaus Al-Hikmah

Boediono.Ekonomi Mikro.UGM: BPFE

Darojat, Dzakiyah, 2000: Kesehatan Mentaj, Bandung: Bulan Bintang

Depag RI.Al-Quran dan Terjemahannya

DepagRI.2002.Islam untuk disiplin Ilmu Ekonomi.Jakarta

Depag RI.2002.Islam untuk disiplin Ilmu Psikolog.Jakarta

Dumairy.1998. Islam dan Ekonomi.Inter IslamicNet

FOKUSMEDIA Tim Redaksi.2009.UNDANG-UNDANG EKONOMI

SYARI'AH, Bandung: F.M. Fokus

Hartono. 2008. Statistik untuk Penelitian. Yogyakarta: Pustaka Pelajar

Irianto, Agus. 2007. Statistik Konsep dasar dan Aplikasinya . Jakarta: Kencana Prenada Media Group

Reksoatmodjo, Tedjo N.2009. Statistika untuk Psikologi dan Pendidikan. Bandung: PT Rafika Aditama

Sugiyono. 2008. Statistika untuk Penelitian. Bandung: Penerbit Alfabeta Bandung 
